\title{
MILTON MT. McKINLEY RANGE EXPEDITION, I96o
}

\author{
By Adams Carter and David Atherton
}

(Toronto)

\begin{abstract}
The paper describes the expedition's work on the north fork of the Eldridge Glacier, which is found to be of the temperate alpine type. Velocity profiles show both slip at the glacier's edge and shear in the adjacent layers. A summer accumulation pattern is demonstrated which makes the glacial balance unusually delicate. It is concluded that glaciers in this region are near their recent maxima because the high altitude accumulation offsets the shrinking of the lower tributary glaciers. Examination of an icedammed lake shows the main Eldridge Glacier to be near the maximum of the last major advance which raised the level of the ice at least $60 \mathrm{~m}$.
\end{abstract}

RÉsumé. Cet article decrit le travail d'une expédition sur la bifurcation nord du glacier de Eldridge, que l'on a trouvé du type alpin tempéré. Les profils de vitesse montrent à la fois un glissement au bord du glacier et un cisaillement dans les couches adjacentes. On met en évidence un schéma de l'accumulation durant la période d'été rendant particulièrement délicate la détermination du bilan glaciare. On conclut que les glaciers dans cette région sont près de leur récent maximum puisque l'accumulation en haute altitude compense le recul des glaciers tributaires inférieurs. L'examen d'un lac de retenue gelé montre que le cours principal du glacier de Eldridge est près du maximum de la dernière grande avance qui avait élevé le niveau de la glace d'au moins $60 \mathrm{~m}$.

Zusammenfassung. Die Arbeit beschreibt die Expeditionstätigkeit an der nördlichen Gabel des EldridgeGletschers, der dem temperierten alpinen typus angehört. Geschwindigkeitsprofile zeigen sowohl Gleitvorgänge am Gletscherrand als auch Schererscheinungen in den benachbarten Lagen. Die Eishaushaltsberechnung wird durch das Auftreten sommerlicher Akkumulation ungewöhnlich schwierig. Man kann schliessen, dass die Gletscher dieses Gebietes beinahe noch ihren letzten Hochstand einhalten, da der Zuwachs in den Hochregionen den Rückgang der tieferen Seitengletscher ausgleicht. Die Untersuchung eines EisStausees zeigt, dass der Hauptstrom des Eldridge-Gletschers fast noch die Maximal-Lage des letzten grösseren Vorstosses besitzt, der die Eisoberfläche um minestens $60 \mathrm{~m}$ hob.

\section{General Introduction}

A reconnaissance expedition made preliminary investigations of the north fork of the Eldridge Glacier during the summer of 1958 . Initial velocity and firn profiles were made and reference panoramas photographed from permanent stations.

The 1960 expedition base camp was established by air at approximately lat. $63^{\circ} \mathrm{I} 3^{\prime} \mathrm{N}$. long. $150^{\circ} 19^{\prime} \mathrm{W}$. on the north fork of the Eldridge Glacier, Mt. McKinley National Park, Alaska, at an altitude of $2,050 \mathrm{~m}$.

The glacier flows $40 \mathrm{~km}$. from its cwm peaks, which reach $3,600 \mathrm{~m}$., to its junction with the main Eldridge Glacier at $800 \mathrm{~m}$., where the surface moraine becomes very extensive. Its average width is nearly $2 \mathrm{~km}$. and it is joined by numerous tributary glacier systems. The firn line is at about $\mathrm{r}, 800 \mathrm{~m}$.

\section{Velocity Profiles}

Velocity profiles were made to determine if the glacier's flow was of the plastic laminar type or if there were indications of Block-Schollen. The movement to width ratio is high $\left(\mathrm{r}: 6\right.$ ) indicating that Block-Schollen movement is likely. ${ }^{\mathrm{I}}$

Figure I shows plots of various profiles:

(A) is a profile measured 24 June to 20 July 1958 at $\mathrm{I}, 600 \mathrm{~m}$.

(B) is a stake line at the edge of the glacier measured 2 to 18 July 1960 at $1,950 \mathrm{~m}$.

(C) is a profile measured 28 June to 20 July 1960 at $2,150 \mathrm{~m}$. A parabola (drawn to the scale of profile $\mathrm{C}$ ) is given for comparison.

The profiles are complicated by the fact that, in this region, the glacier is nowhere straight and uninterrupted but is joined by many tributaries; also the few outcrops of rock bounding the valley are generally unsafe for survey stations.

Profiles B and C show slip at the edges of the glacier. This is suggested by the comparatively small lateral moraines. The valley sides are precipitous frost-shattered shale producing, in places, rock falls that, during milder weather, are continuous; they would rapidly build 
large lateral moraines were it not for the slip of the glacier at its edge. It should be noted that, since the profiles ended on exposed bedrock, the actual ice-rock interface being concealed by small amounts of avalanche snow and surface moraine, the apparent slip must be slightly increased to allow for this edge correction.

There is also considerable shear towards the edge of the glacier which is indicated by the vigorous crevassing in this region. This would seem to be the main factor producing the unusually high velocities of the marginal laminae of the glacier. The amount of shear seems unexpectedly large but it should be noted that profiles B and C, in which it is most marked,

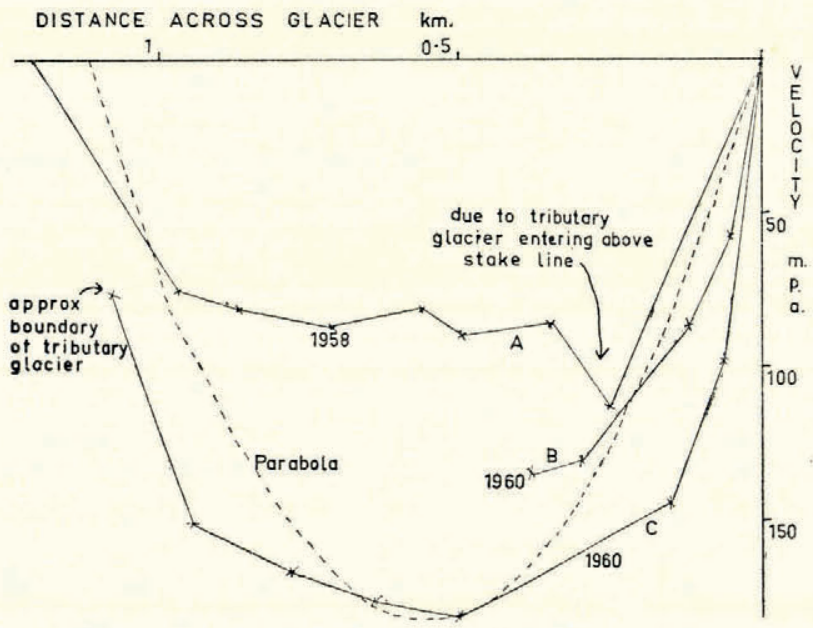

Fig. I. Velocity profiles

are both made in the cwm region and, due to incomplete consolidation of the upper firn layers, resistance to shear will be unusually low, especially at the edges of the glacier where the ice itself is thin and the poorly compacted firn forms an appreciable part of the glacier's total thickness.

A longitudinal line of stakes at 2,050 m. measured between 2 and 29 July ig6o showed a compression of less than 0.05 per cent.

Movements of prominent moraines below profile $\mathrm{C}$ between the reference photographs taken in $195^{8}$ and 1960 and the aerial photographs taken in 1952 and 1957 are compatible with the velocity obtained from profile $\mathrm{C}$ and do not suggest any recent marked change of velocity.

\section{Meteorological Observations}

Figure 2 gives the maxima, minima and mean temperatures at base camp. It should be noted that these are not directly comparable with other stations since a modified lightweight type of Stevenson screen was used, with thin metallic louvres designed specially to reduce the thermal time delay. Compared with a standard instrument box, the minima are probably a trifle lower and the maxima considerably higher. The thermograph record was much more sensitive than usual, and it is felt that this is a more realistic approach than the conventional method.

Figure 3 shows the processes of accumulation and ablation. A dirt layer was formed at $-53 \mathrm{~cm}$. with a small thin ice layer and will probably persist.

The annual cycle of accumulation is unusual since the main accumulation period is during the early autumn when temperatures have not yet become severe. The ablation cycle is fairly 


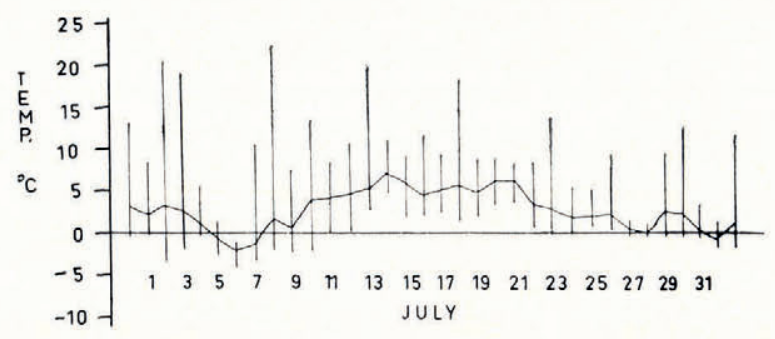

Fig. 2. Temperalure ranges and means

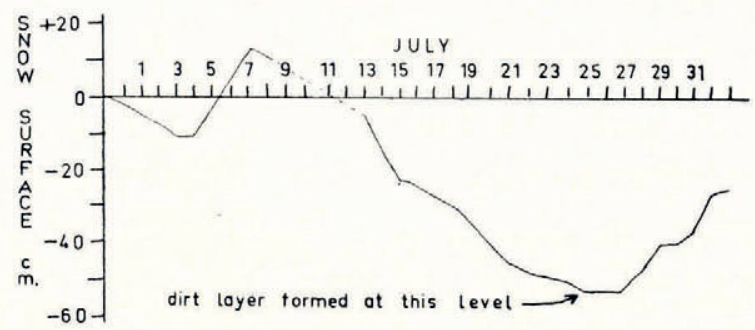

Fig. 3. Daily snow surfaces

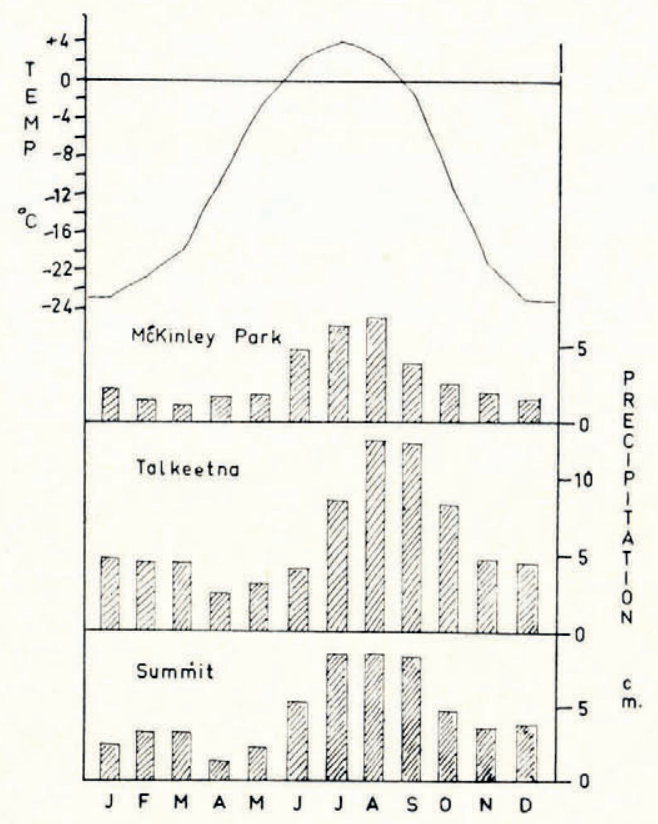

Fig. 4. Local meteorological records

regular having a maximum shortly after the summer solstice; wind and cloud cover will have irregular disturbing effects on the pattern. The main precipitation is during the late summer and autumn. Figure 4 summarizes these cycles from the data compiled by the local meteorological stations at Summit, McKinley Park and Talkeetna. ${ }^{2} \mathrm{~A}$ graph of average mean monthly temperatures corrected to firn-line height is given. The precipitation charts all show 55-6o per cent occurring during the four months at the end of the summer; this 
effect is probably even more marked in the high accumulation zones. During this season precipitation generally occurs on the cooler days so that the likelihood of snow rather than rain is greater than the charts suggest.

The net accumulation occurs therefore largely in the autumn; the winter accumulation is small and, during the late spring and early summer, this appears to be melted away to considerable altitudes, as we found by measuring firn temperatures. The firn profiles themselves, with the numerous summer ice bands, are conclusive evidence of this summer accumulation pattern.

The period of our observation seems to cover the end of the ablation and the start of the accumulation processes.

This type of summer accumulation, as opposed to the more usual process of winter accumulation and summer ablation, leads to a rather delicate balance between the glacier equilibrium and the climatic conditions. During the summer, precipitation occurs at or about the freezing point, falling on the lower part of the glacier as rain and in the higher cwm area as snow. The latent heat of fusion of ice means that, although the snow and rain falling at different altitudes on the glacier may be at approximately the same temperature, there is a vast difference in their contributions to the glacier's thermal budget: the rain contains its latent heat of fusion by reaching equilibrium with the air over a considerable atmospheric height; the snow, when it has fallen, can only gain its latent heat of fusion by radiation or by convection and conduction with the air in the layer directly above the glacier's surface, so that its potential heat source is very much less. Another factor is dirt on the snow: fresh snow is whiter and absorbs less heat by radiation, so that a succession of small snow falls will take longer total time to ablate than the same amount of snow in one bigger fall.

A small change in the summer climatic conditions may therefore produce a big alteration in the glacier's equilibrium as we found to have occurred between r $95^{8}$ and r 960 .

\section{Firn Profiles and Mrasurements}

Density

Since the main accumulation is during the late summer when there may also be melting, the snow falling is mostly wet and dense; it is then further compacted by surface melting and by wind. Surface firn densities measured were high, of the order of $0.5 \mathrm{~g} . / \mathrm{cm} .^{3}$ increasing typically to $0.6 \mathrm{~g} . / \mathrm{cm} .{ }^{3}$ at a depth of about $2 \mathrm{~m}$.; firn stratification may cause local variations of 20 per cent.

\section{Temperature}

Firn temperatures were measured with freezing point thermometers in the cores obtained by drilling and by suspending the thermometers, thermally lagged to achieve a time delay, in the holes drilled and also by inserting them in the sides of snow pits; this last seemed the most sensitive method.

Table I shows the temperatures measured in a $3.5 \mathrm{~m}$. snow pit. Temperatures during drilling varied from $0 \cdot 4^{\circ} \mathrm{C}$. to $0^{\circ} \mathrm{C}$. typically and $+\mathrm{I} \cdot 4^{\circ} \mathrm{C}$. to $-\mathrm{I} \cdot \mathrm{O}^{\circ} \mathrm{C}$. in extremes at depths up to $12 \mathrm{~m}$. These slight variations appear to be uncorrelated and are not considered to be significant. It seems that the whole mass is at a temperature very close to its melting point; there is no evidence of cold waves being transmitted down through the firn or of cold layers trapped in the firn. We deduce that the whole of the cold surface layer formed during the winter is melted away during the early summer before the accumulation during the late summer and autumn, which occurs close to the freezing point, and that the glacier is of the temperate alpine type. It is possible that at higher altitudes cold layers are preserved in the firn but, considering the soft snow conditions that we found on visits to the upper accumulation zones, the winter cold layer is probably destroyed each year at altitudes of $2,700 \mathrm{~m}$. or more. 
Table I. Snow Pit Firn Temperatures Measured at 2,050 m.

$\begin{array}{cc}\begin{array}{c}\text { Depth } \\ \mathrm{cm} .\end{array} & \begin{array}{c}\text { Temperature } \\ \text { OC. }\end{array} \\ & \\ 15 & -0 \cdot 05 \\ 30 & 0 \cdot 0 \\ 46 & 0 \cdot 05 \\ 61 & -0 \cdot 05 \\ 76 & 0 \cdot 0 \\ 91 & 0 \cdot 0 \\ 107 & 0 \cdot 0 \\ 122 & -0 \cdot 05 \\ 137 & -0 \cdot 05 \\ 152 & -0 \cdot 15 \\ 168 & 0 \cdot 0 \\ 183 & -0 \cdot 05 \\ 198 & -0 \cdot 15 \\ 213 & 0 \cdot 0 \\ 229 & 0 \cdot 1 \\ 244 & -0 \cdot 05 \\ 259 & -0 \cdot 15 \\ 274 & -0 \cdot 1 \\ 290 & -0 \cdot 1 \\ 305 & 0 \cdot 0 \\ 320 & -0 \cdot 1 \\ 335 & -0 \cdot 05\end{array}$

\section{Firn Stratification}

Experience of the topography of the accumulation zone and of the meteorological conditions prevailing there during typical accumulation periods, when a complicated system of wind eddies is set up, suggests that the accumulation pattern must be highly irregular and critically dependent upon wind velocity and direction and the prevailing temperatures. In addition, the pattern of summer accumulation tends to form many ice layers in the firn during the summer without leaving any well-defined dirt layer. The examination of the firn stratification found in the core samples, obtained by drilling, is therefore unusually difficult and care should be taken in the interpretation of these results.

Figure 5 is a simplified scale presentation of the ice bands found in the snow pits and drill holes. Tentative correlation lines and summer surfaces are indicated, but much of the evidence for these is contained only in the detailed records of the texture of the firn. It was unfortunate that in many of these holes the firn had a tendency to deteriorate into consolidated banded ice, which obscured any other stratification, and that, despite thoughtful selection of sites, three of the holes struck crevasses; however, these conditions may well be typical.

The interpretation is aided by the snow pit dug by the reconnaissance expedition in 1958, which keys in well, and the $2 \cdot 2 \mathrm{~m}$. accumulation for 1959, so indicated, agrees well with that observed in open crevasses. The 1956 ice layer, caused by an unusually warm dry summer, is also a prominent feature though it appears to be missing from profiles A and B and their increased altitude does not seem an altogether satisfactory explanation. Comparison of the estimated annual layers with the regional meteorological records shows good correlation. ${ }^{2}$

The increase of accumulation with height appears to be slight and local effects are probably of greater importance. Differences between net annual accumulations are striking though. It is of particular interest to compare the five years prior to $195^{1}$ with a similar period directly before or after; in both cases the total accumulations have been about twice as much. The mass of ice in the cwm, and hence the forward pressure on the glacier, must therefore have diminished temporarily so that the glacier's velocity will have decreased and then increased again. This type of velocity fluctuation applied to a potentially unstable glacial system might be sufficient to trigger a very large movement such as occurred on the adjacent Muldrow glacier in $1957 .^{3}$ 


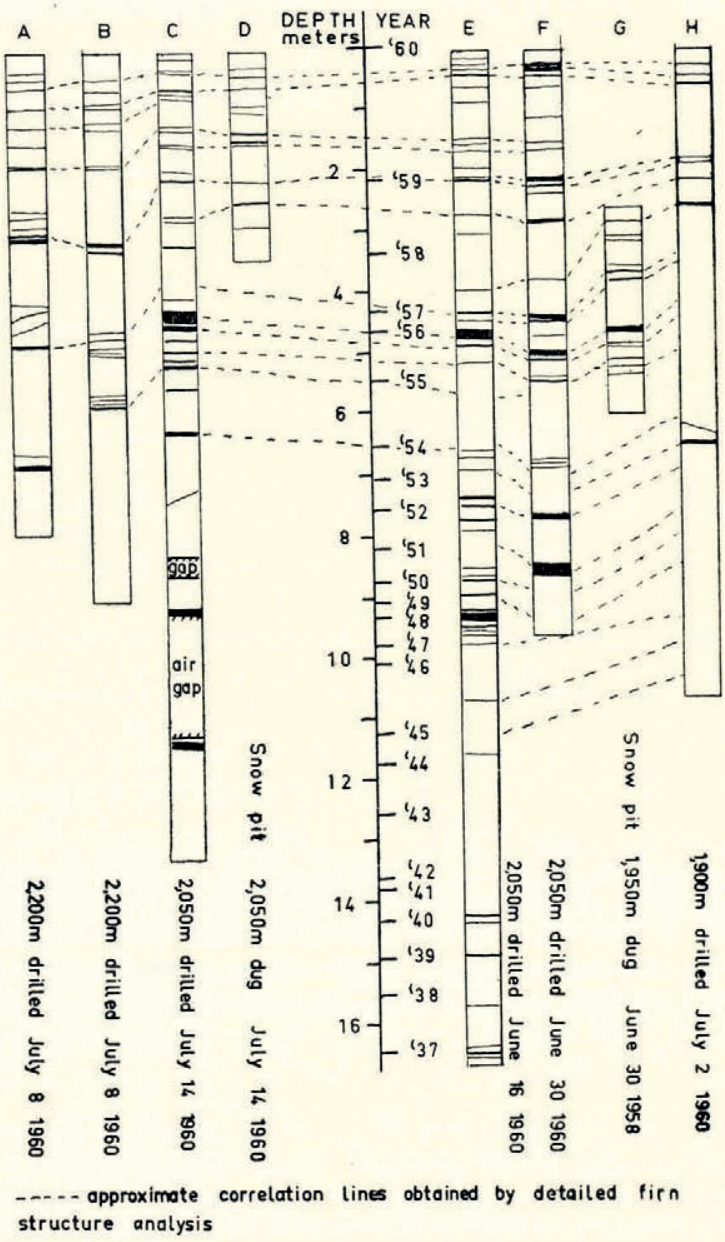

Fig. 5. Ice bands in firn (to scale). Summer snow surfaces at 2,05o m. are shown. Correlation lines join similar sequences of siratified firn structures, usually with ice bands as prominent features, though in some cases correlations have been made between ice bands and layers of dense, coarsely crystalline firn in fine, loose snow, etc. Ice bands only are shown here. Summer snow surfaces marked are the ends of gradual transition sequences in the firn texture, ideally from fine, loose snow to coarsely crystalline ice bands

\section{Surface Features and Observations}

Firn lines are estimated from aerial photographs for $195^{2}$ and 1957 and from field studies in $195^{8}$ and 1960 as follows:

$\begin{array}{ll}\text { I952 } & \text { I,780 m. } \\ \text { I957 } & \text { I,860 m. } \\ \text { I958 } & \text { I, } 820 \mathrm{~m} . \\ \text { I960 } & \text { I,800 m. }\end{array}$

The very high 1957 level agrees with the very large ablation found to have occurred over the previous year by Adams Carter investigating Dr. F. A. Cook's "summit" of Mt. McKinley in $1957^{4}$ and with the 1956 ice layer found in the firn profiles.

Reference photographs taken in 1958 , when compared with those taken in 1960 , of which Figures 6 and 7 (p. I I29) are an example, reveal a very considerable increase in the snow 


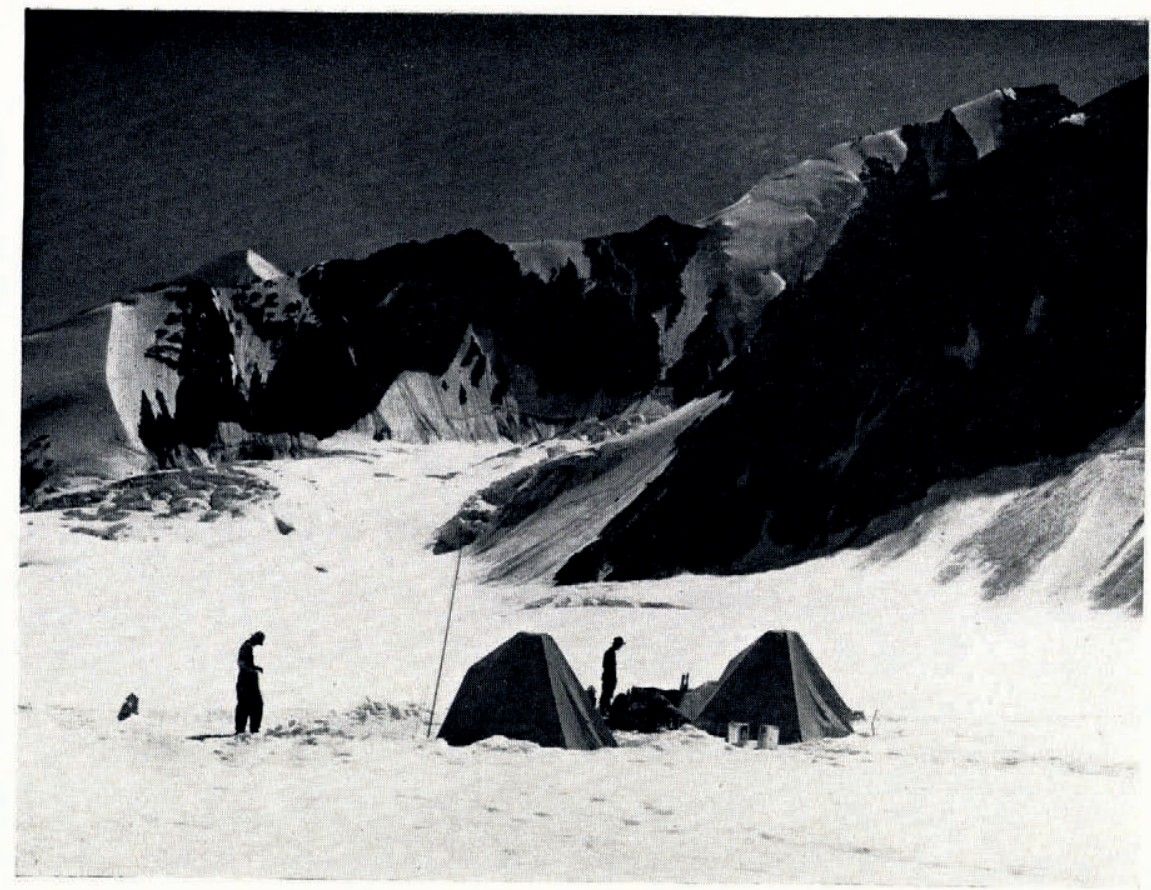

Fig. 6. Tributary of north fork of Eldridge Glacier-7uly $195^{\circ}$

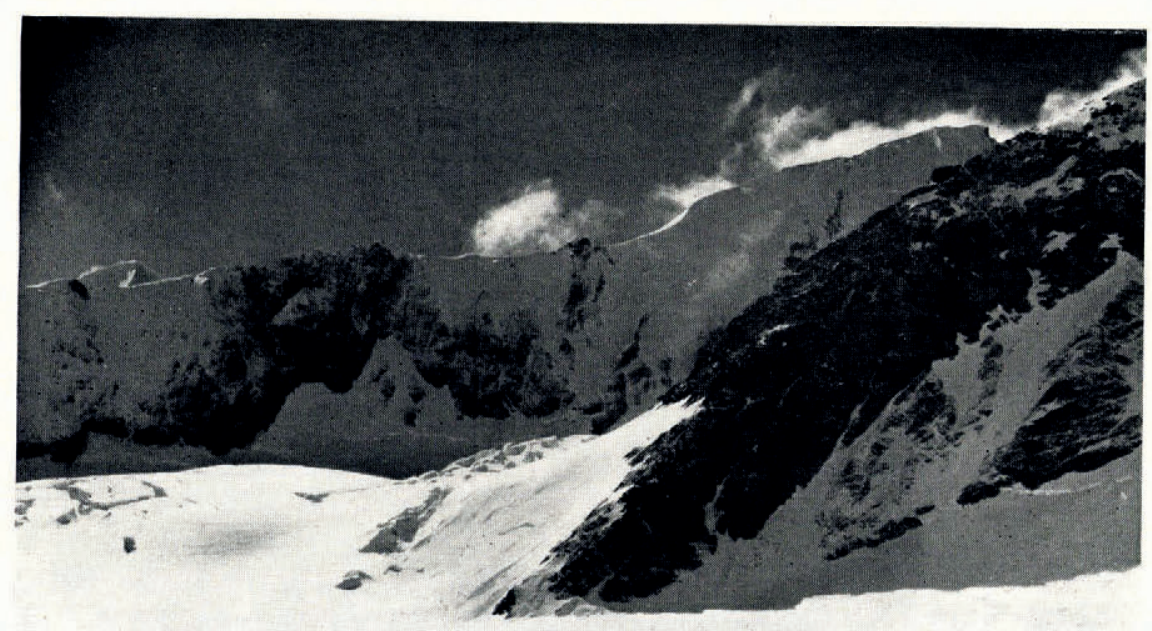

Fig. 7. Same view as Figure 6 taken. 7uly 196o. Comparison with the $195^{8}$ photograph shows that underneath the light snow coverage, due to a recent fall, many previously exposed rock faces are now covered with permanent snow 


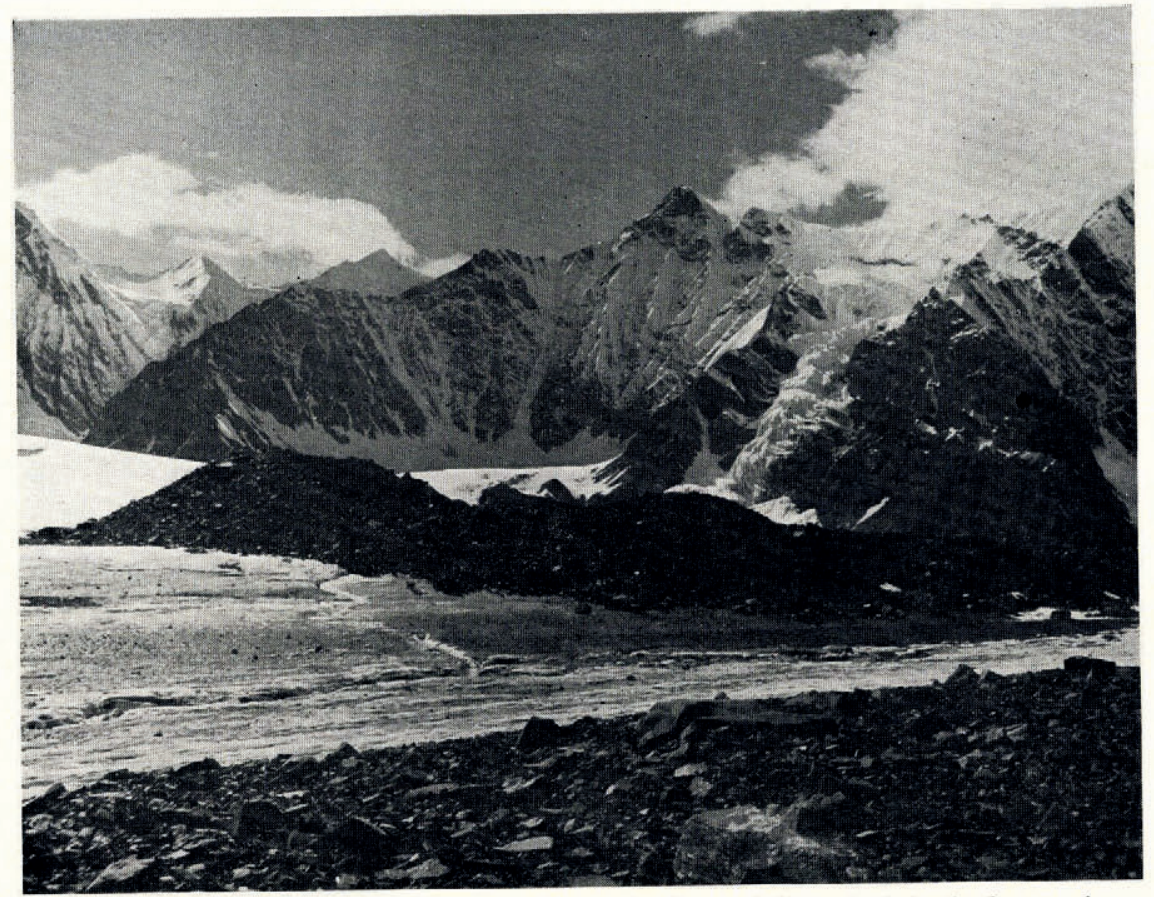

Fig. 8. Barchan-shaped portion of medial moraine. Another medial moraine is in the foreground

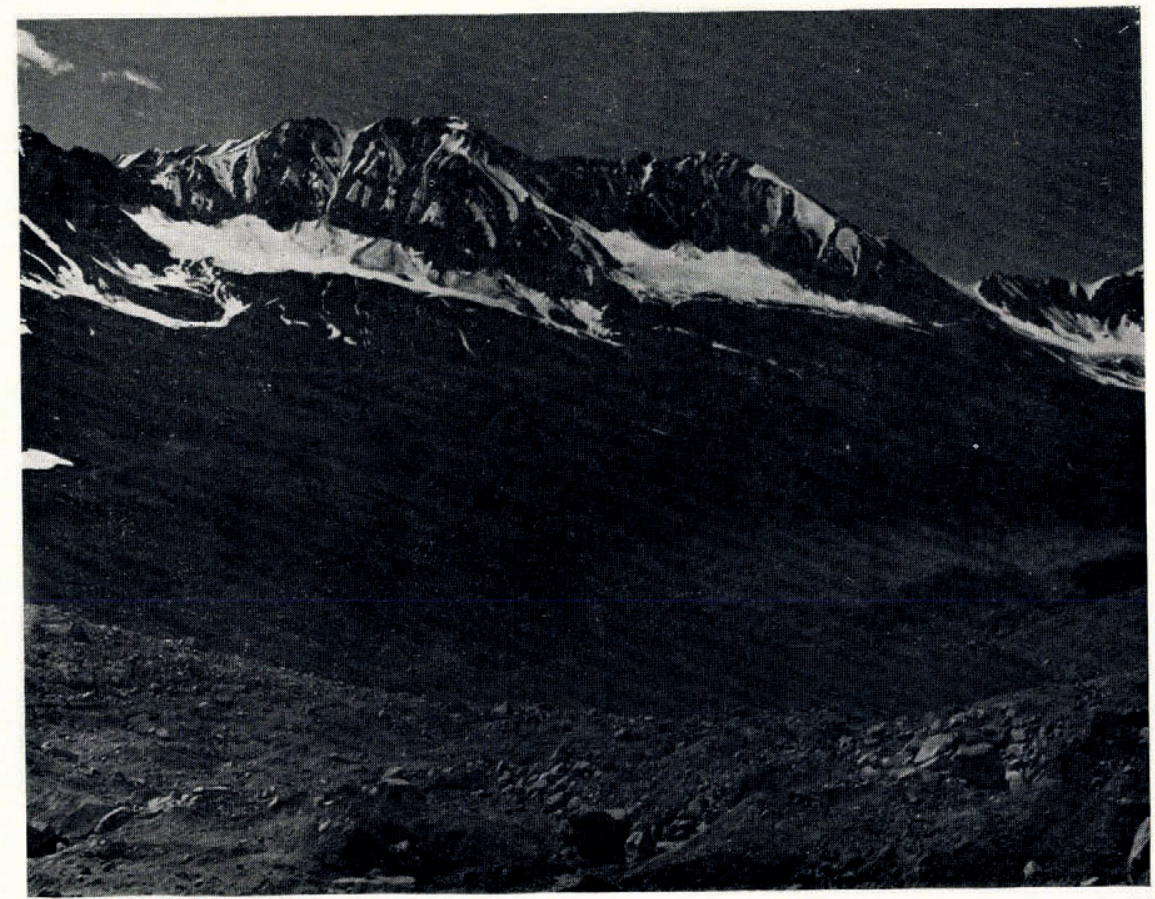

Fig. 9. Ice-dammed lake. In the foreground is the lateral moraine forming the inner dam. The numerous raised beaches are clearly visible

1130 
coverage right down to the firn line, that is most clearly evident on the lower glaciers on the southern or western side; in some places it is also possible to discern a slight rise in the level of the ice. One of the upper observation cairns had been covered with II $5 \mathrm{~cm}$. of hard packed snow since it was originally built on exposed rock in 1958. The increase in the size of the avalanche fans was especially noticeable, as would be expected, because an avalanche fan forms an efficient collection system for the summer snow, since, when after falling it melts sufficiently to avalanche, it is concentrated over a much smaller area in the avalanche fan so that it melts more slowly there.

The main accumulation zone appears adequately vigorous to maintain the present glacial balance. The ice below the firn line is remarkably free from surface disturbances suggesting that it is hardly moving but this is definitely not the case, and movements of moraines are detectable in the aerial photographs quite close to the main junction. Although the lower tributary glaciers do seem to be melting away, especially on the eastern side, these corrie glaciers would provide relatively little nourishment for the main glacier in any case.

The characteristic rock of the area is shale and extremely susceptible to frost shatter; in some places there was a steady trickle of small rocks, at others, frequent rock falls, and it seems likely that very big rock falls also occur from time to time. Several of the small cirque glaciers in the region are almost completely rock covered; strongly contorted medial moraines are to be seen on some of the glaciers, which must indicate very erratic movement of the tributary glaciers.

At about $\mathrm{I}, 600 \mathrm{~m}$. the north fork of the Eldridge is joined by its largest tributary and just beneath the confluence there are two barchan-shaped moraines (Fig. 8, p. i i 30) that appear to have originated from very big rock falls on the northern side of the tributary near the junction; probably the addition of such a vast weight of rock considerably increased the speed of flow in the corrie, but even so the shape of these moraines seems to indicate a rather unusual velocity distribution in the tributary since, although they are near the northern edge of the glacier, both arms of the barchan shape are orientated sharply up-glacier.

Trim lines and lateral moraines are not much in evidence on the valley sides of the north Eldridge. Suggested hanging valleys and truncated spurs on the eastern side of the lower part suggested a possible ice line about $100 \mathrm{~m}$. above the present level, but the vegetative covering indicates that this must certainly have been many centuries ago. Nearer to the junction with the main Eldridge, small trim lines were discernible on both sides of the glacier, the most distinct being some $30 \mathrm{~m}$. above the present ice level and the others lower, with good vegetation above the highest. In places, the level of the present moraine on the glacier seemed to be above the lowest signs of vegetation on the valley sides, possibly indicating a rise in the level of the ice and certainly there seems to be no evidence for recent retreat.

Traversing the main Eldridge opposite the confluence there is, on the eastern side, one very clear lateral moraine I $5 \mathrm{~m}$. high with vegetation well advanced, which cannot be less than fifty years old, probably considerably more. Two big medial moraines are impressive, being over $30 \mathrm{~m}$. high, and a third to the west is not much smaller. On the western side of the glacier trim lines are visible at about $45 \mathrm{~m}$. above the ice.

\section{ICE-DAmmed LAKe}

A special visit was made to an ice-dammed lake on the south side of the main Eldridge glacier, directly opposite its conflux with the north fork, in order to study the system of raised beaches.

The lake itself (Fig. 9, p. I 1 30) is at an altitude of approximately $750 \mathrm{~m}$. and is about one third of a kilometer across; it is fed by a glacial river from the valley directly behind it. On our visit on I 2 July it was dammed first by the glacier's lateral moraine, through which a single overflow channel had been cut; outside this a sheer wall of glacial ice formed another dam of approximately the same height, the lake emptied under this through a tunnel. When 
we flew over the lake on 27 June, the level of the lake was much higher and covered much of the lateral moraine.

The bowl shaped sides of the lake, which are themselves incised in a broad glacial valley, show a series of small raised beaches. There was a particularly well defined one at an elevation of $53 \mathrm{~m}$. above the surface of the lake on I 2 July; the ice cliff also had a very prominent water line at this height, the ice beneath was undercut and water worn; this was presumably the level of the lake on 27 June. Above this level some twenty more raised beaches may easily be distinguished, reaching to a height of $100 \mathrm{~m}$. above the level of the lake on 12 July, some of the upper ones are much obscured by vegetation, but, in general, these beaches are large and distinct and are spaced at fairly regular intervals. Below this level there are also many prominent beaches, but lower down they tend to become finer and closer together and in many places they are separated by only a few centimeters; they seem to be genuine raised beaches rather than varves or other stratification, since they are surface features only and they dip slightly towards the lake.

The aerial photographs of 5 September 1957 show the lake to be very close to the level we saw on 12 July; however those of 21 July 1952 show the lake with a level near to that seen by us on 27 June, so that it is possible that the lake may have remained at a relatively high level all that year.

At present it seems evident that most years the tunnel under the ice becomes blocked during the winter and, when the summer thaw comes, the level of the lake rises until it drains through a channel on the glacial side of the lateral moraine; a high-level beach is formed. Later in the summer the drainage may revert to subglacial and low-level beaches are formed.

In postulating a sequence of events there are several independent time-scale indications that can be used to estimate minimum elapsed time. A possible sequence of events would start with the glacier at a level considerably lower than at present with the lake depression being incised into the "U" shaped glacial valley by a river. Next, the level of the glacier rises and a lateral moraine is deposited across the valley; a moraine-dammed lake is formed, which drains between the moraine and the mountainside. During this stage the highest raised beaches are formed; the vegetation now found on them suggests that this stage must have been at least a hundred years ago and probably more; the size of the lateral moraine indicates a duration of fifty to a hundred years absolute minimum as it appears not to be icecored; on the other hand, infilling of the lake puts an upper limit on the duration of this stage. Later the lateral moraine is breached in the middle (probably initiated by a small retreat of the glacier) and a drainage channel is established over the ice between the lateral moraine and the glacier; the summer subglacial drainage cycle is probably started soon afterwards. The number of raised beaches (counting one large, high spring one and several lower summer ones normally formed per annum) and the size of the breach made in the lateral moraine, both suggest that this must have been going on for about fifty years.

In broad outline this theory implies that about two hundred years ago at a minimum the glacier was lower by at least $60 \mathrm{~m}$. and that there was then a big advance and that since then the glacier has more or less maintained this level. At present the glacier must be close to its maximum during this period, since it is at approximately the same level as the lateral moraine and, allowing for the depth of the surface overflow channel, the lake could approach its maximum extent.

\section{MS. received 31 January 1961}

\section{REFERENCES}

I. Finsterwalder, R. Some comments on glacier flow. Journal of Glaciology, Vol. I, No. 7, 1950, p. 383-88.

2. U.S. Weather Bureau. Climatological Data. Alaska Section, Vols. 33-45.

3. Post, A. S. The exceptional advances of the Muldrow, Black Rapids, and Susitna Glaciers. Fournal of Geophysical Research, Vol. 65, No. I I, 1960, p. 3703-12.

4. Washburn, B., and others. Doctor Cook and Mt. McKinley, by B. Washburn and Ann and Adams Carter. American Alpine Fournal, Vol. I I, No. I, 1958, p. I-30. 